\title{
ZACHRÁNCE Z ČESKÉ OBCE KUPIČOV NA VOLYNI - K ŽIVOTNÍM OSUDŮM EVANGELICKÉHO DUCHOVNÍHO JANA JELÍNKA
}

\author{
Lenka Kločková - Roman Štér
}

\begin{abstract}
A rescuer from the Czech village of Kupičov in Volhynia: on the life and fortunes of the Evangelical clergyman Jan Jelínek
\end{abstract}
\begin{abstract}
The purpose of this text is to map out the vicissitudes in the life of the Evangelical clergyman Jan Jelínek on the basis of the sources available, in a bid to foster awareness of this prominent personage in the public realm and preserve his memory for future generations. Jan Jelínek was born in 1912 in Zelov (present-day Poland) to Czech exiles. Initially he worked as an accountant in the Jan Sláma company in Zelov, later graduating from the Missionary School in Olomouc and becoming a preacher. In the years 1937 - 1944 he served as preacher in the Czech village of Kupičov in Volhynia. During World War II he helped the persecuted, hiding Jews from the Germans, and Ukrainians and Poles from Bandera's followers. In 1944 he and his wife joined the First Czechoslovak Army Corps in the USSR. In January 1958 he was arrested by the StB (the secret police of the Communist Czechoslovak state), and following three months of detention on remand, was sentenced to two years in prison for sedition and opposition to the establishment of the JZD (a network of Czech collective farms). He was released in 1960. Until his retirement in 1972, he worked as a labourer in the Paints and Varnishes company. Jan Jelínek died in Prague in 2009. On 28 October 2019 president Miloš Zeman posthumously decorated him with the Order of Tomáš Garrigue Masaryk, Class I.
\end{abstract}

Keywords: Jan Jelínek - World War II - rescue of Jews - Volyhynian Czechs - anti-communist - post-White-Mountain exile

Contacts:

PhDr. Kločková Lenka, Národní archiv, Archivní 2257/4, 14900 Praha 4; e-mail: Lenka.Klockova@nacr.cz

Bc. Štér Roman, Národní archiv, Archivní 2257/4, Praha 4, 149 00; e-mail: Roman.Ster@nacr.cz

Národní archiv kromě fondů úřední provenience pečuje rovněž o archiválie nestátní provenience. Tomuto úkolu se od svého vzniku v roce 1996 věnuje VI. oddělení Národního archivu, které se zaměřuje mimo jiné na získávání osobních fondů významných osobností politického a společenského života, osobností, které výrazným způsobem ovlivnily či dokumentovaly dějinný vývoj naší země. Díky systematické akviziční činnosti a trpělivě budovaným vztahům s původci a držiteli archiválií si Národní archiv v této oblasti získal značný respekt.

Fondy Národního archivu v roce 2010 významně obohatil také osobní archiv evangelického duchovního Jana Jelínka. Jeho životní osudy jsou výjimečné, stejně jako je výjimečná jeho osobnost. Č́ást jeho života, ta nejvíce dramatická, je nerozlučně spjatá s ukrajinskou Volyní. Za svého života byl Jan Jelínek osobností, kterou znal především široký okruh volyňských Čechů, nejen rodáků z volyňského Kupičova, a věřících Českobratrské církve evangelické.
Jan Jelínek, zelovský rodák, zachránce mnohých lidských životů, příslušník československého zahraničního protinacistického odboje, v padesátých letech politický vězeň, nikoli náhodou získal př́idomek ,český Oskar Schindler". V době druhé světové války, kdy působil jako evangelický kazatel v české obci Kupičov na Volyni, na své faře poskytl úkryt a pomoc pronásledovaným lidem bez rozdílu vyznání či národnosti a díky své šlechetnosti a odvaze zachránil život desítkám lidí.

Do povědomí širší veřejnosti se životní příběh Jana Jelínka dostal poté, co mu v červenci 2008 náčelník Generálního štábu Armády ČR, gen. Vlastimil Picek udělil „Plaketu náčelníka generálního štábu“ a „Laudi Memorabilis“ za neokázalé hrdinství a skutky, jimiž zachránil desítky lidských životů nejen za války, ale také v pohnuté poválečné době. O rok později Jan Jelínek zemřel dne 3. prosince 2009 v Ústřední vojenské nemocnici v Praze. 


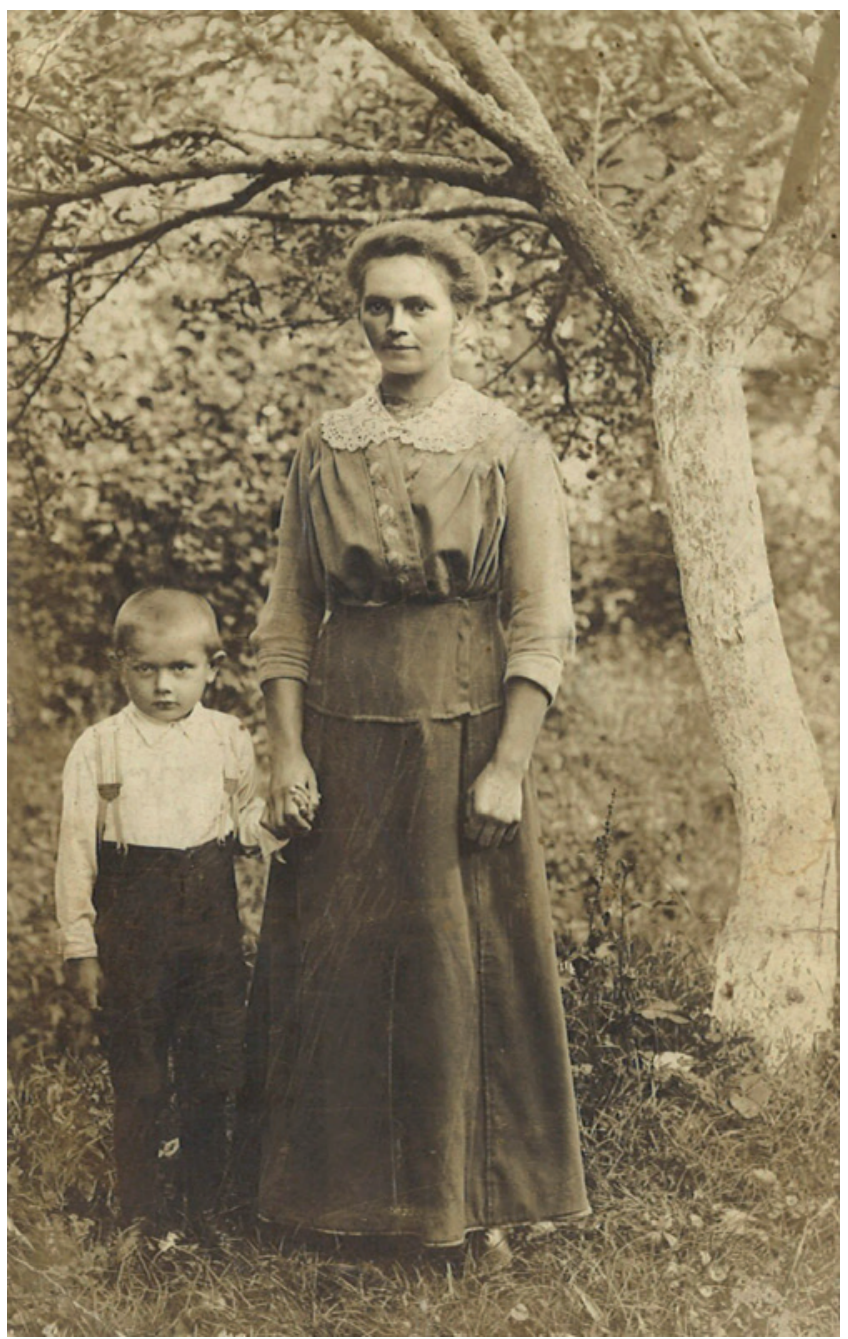

Obr. 1. Jan Jelínek s maminkou (rok 1916). NA f. Jan Jelínek, nezpracováno.

Jakou cestou se k nám písemnosti Jana Jelínka dostaly? Když 3. prosince 2009 Jan Jelínek zemřel, vysílala ČT 1 ve své hlavní zpravodajské relaci zprávu o jeho skonu. Byli jsme přesvědčeni, že odkaz takových statečných lidí, jakým byl Jan Jelínek, má být uchován v paměti národa pro další generace, proto jsme oslovili pana Josefa Řepíka, který byl v té době předsedou historicko-dokumentační komise Sdružení Čechů z Volyně a jejich přátel, a poprosili jsme ho, zda by nám pomohl navázat kontakt s rodinou Jana Jelínka. Kontakt s neteří Jana Jelínka, paní Evou Jelínkovou, nám poté laskavě zprostředkovala rodačka z Kupičova, paní PhDr. Miloslava Žáková, CSc. Díky této skvělé spolupráci se nám podařilo $\mathrm{s}$ rodinou vyjednat předání osobního archivu Jana Jelínka a jeho manželky Anny do Národního archivu.

Osobní archiv Jana Jelínka obsahuje životopisné materiály (osobní doklady, legitimace), korespondenci (včetně dopisů, které psal Jan Jelínek v době svého věznění v 50. letech své manželce), písemnosti vztahující se k politickému procesu s Janem Jelínkem v roce 1958 a z pozdější soudní rehabilitace, dokumenty související s duchovní službou Jana Jelínka. Dále jsou ve fondu uloženy dochované texty Jelínkových kázání, fotografie, novinové výstřižky o životě Jana Jelínka, rozhovory, které poskytoval tisku, atd.

Získání osobního archivu Jana Jelínka nás inspirovalo k zpracování této studie, ve které jsme se soustředili nejen na popsání bohatého života Jana Jelínka. Chtěli jsme především prripomenout a pokusit se zmapovat odbojovou činnost jmenovaného za druhé světové války. Tomuto tématu podle našeho názoru nebyla dosud věnována taková pozornost, jakou by si zasloužilo. Stranou naší pozornosti zůstala Jelínkova činnost v rámci Československé církve evangelické, které zasvětil celý svůj život. Toto téma by si ale zasloužilo samostatnou studii. ${ }^{1}$

Při psaní studie jsme využívali jednak písemnosti uložené v osobním archivu jmenovaného, ale také vzpomínky Jana Jelínka, které představují zásadní pramen k poznání jeho činnosti za druhé světové války, o které se v archivních institucích nachází minimum dokumentů. Pokud se týká archivních pramenů, při psaní studie jsme využili zejména písemnosti uložené v osobním fondu Jan Jelínek, dále archiválie uložené v Archivu bezpečnostních složek ve Sbírce Správa vyšetřování StB - vyšetřovací spisy, dokumenty nacházející se ve Vojenském historickém archivu, kde jsme dohledávali archiválie vztahující se k Janu Jelínkovi ve Sbírce dokumentace oddělení pro vydávání osvědčení MO ČR. Po dokumentech, které by osvětlily život a duchovní činnost Jana Jelínka, jsme pátrali rovněž v Archivu Kanceláře prezidenta republiky a v Ústředním archivu Českobratrské církve evangelické. Získané poznatky z výše jmenovaných archivů jsme konfrontovali s textem Jelínkových vzpomínek.

\section{Cesta ke službě Bohu}

Životní pout' Jana Jelínka, potomka českých pobělohorských exulantů, ${ }^{2}$ začala 19 . května 1912 v polském Zelově, ${ }^{3}$ v části Polska, která tehdy patřila carskému Rusku. Jeho rodiče, Pavel Jelínek a Karolína Jelínková, roz. Jersáková, pracovali jako textilní dělníci. Když byly Janovi dva roky, otec narukoval do carské armády a svého syna spatřil až po jejím skončení.

Od roku 1918 navštěvoval Jan základní sedmitřídní školu v Zelově, v roce 1924 pak začal navštěvovat měšt'anskou školu v Suchdole nad Odrou. Prarodiče Jana Jelínka, manželé Jersákovi, se totiž v tomto roce přestěhovali do Československa a třináctiletý Jan, který si k nim vytvořil hlubokou citovou vazbu, podobně jako $\mathrm{k}$ mamince, je zakrátko následoval, a sice jako černý pasažér. Více tuto událost popsal v knize svých vzpomínek. ,,Odjižděli jsme ze stanice vzdálené asi $10 \mathrm{~km}$ od Zelova. [...] Já jsem byl ještě s jedním chlapcem, Vilémem Špringlů, černý pasažér. Na hranici mezi Polskem a Československem jsme se museli schovat do diže pod stolem, aby nás celníci nenašli a neposlali zpět. Celníci důkladně prohliželi vnitřek vagónu, nicméně do diže pod stolem se nepodivali. Pak náš vagón přejel hranice a my

Této problematice se byt’ pouze okrajově věnoval Pavel Keřkovský. Viz Pavel KEŘKOVSKÝ, Jan Jelínek, in: P. HLAVÁČ - P. MORÉE, Cesta církve VI, Praha 2012, s. 12-34.

2 K historii pobělohorských exulantů bliže např. Edita ŠTĚříKOVÁ, Země otců, Praha 1995; dále Edita ŠTĚŘíKOVÁ, Stručně o pobělohorských exulantech, Praha 2005.

K historii obce srv. Edita ŠTĚříKOVÁ, Zelów, Česká exulantská obec v Polsku, Praha 2010. 


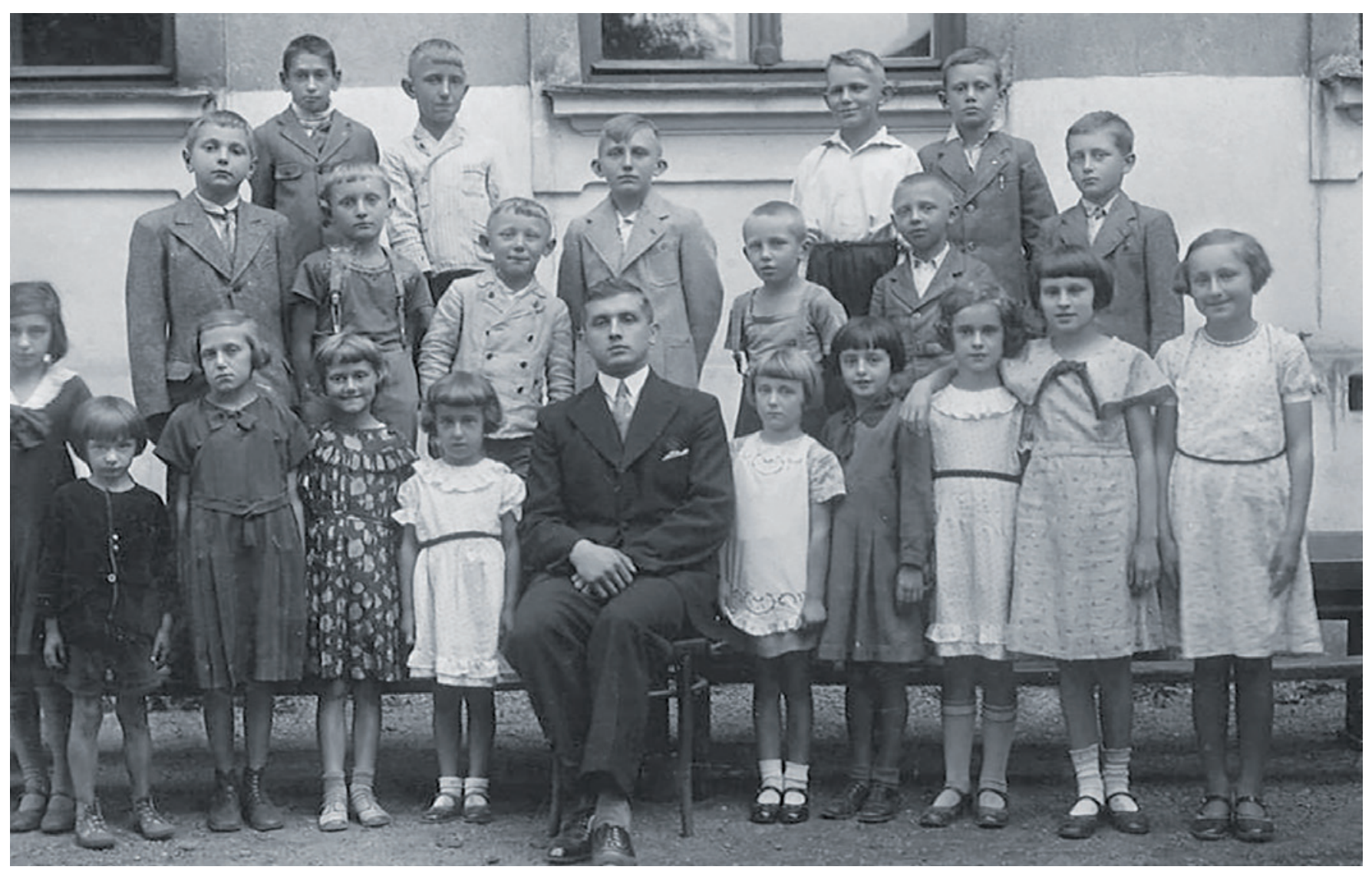

Obr. 2. Jan Jelínek s dětmi v době svých studií teologie na Misijní škole v Olomouci, rok 1932. NA f. Jan Jelínek, nezpracováno.

jsme se ocitli v Čechách, v naší vlasti. "“ Kromě školní docházky Jan také pracoval na dědečkově hospodářství.

O tři roky později, v roce 1927 , se vrátil k rodičům do Zelova a pracoval v české tkalcovské firmě Jan Sláma. Zde, již v pouhých patnácti letech, vedl celé účetnictví, navíc při práci soukromě studoval textilní průmyslovku.

V letech 1931-1935 pak studoval teologii v Misijní škole v Olomouci. K víŕe v Boha přivedla Jelínka jeho maminka. Později často četl duchovní literaturu, kde ho zaujaly články o pohanské misii, a zatoužil stát se kazatelem. ${ }^{5}$ Svůj vliv na Jelínkovo rozhodnutí mělo také prostředí, ve kterém vyrůstal, a rodinné kořeny. Po absolvování Misijní školy se vrátil zpět do Zelova, kde opět působil ve stejné textilní firmě, kde před lety vedl účetnictví. Tentokrát však již celou továrnu, která se mezitím rozrostla a měla již 150 zaměstnanců, rídil.

\section{Pomoc potřebným}

Když v roce 1937 dostal nabídku působit jako kazatel v evangelickém sboru na Volyni, ${ }^{6}$ rozhodl se ji přijmout. Na Volyni našel i svoji lásku, v roce 1942 se oženil s Annou
Blažkovou (1918-2008). Spolu prožili bezmála sedmdesát let. Jelínek se stal kazatelem v české obci Kupičov. Právě zde zažil v době druhé světové války nejdramatičtější a také nejnebezpečnější chvíle svého života, ale jak sám Jelínek říká, také roky nejbohatší. Díky své statečnosti a šlechetnosti, kterou v této době prokázal, získal od bývalých obyvatel české obce Kupičov přídomek ,„̌eský Oscar Schindler“. Jan Jelínek ve svých vzpomínkách, které byly vydány v roce 2003 pod názvem Pouštěj chléb svi̊j po vodě, ${ }^{8}$ na své počátky v Kupičově vzpomíná takto: ,, Měl jsem zvěstovat slovo lásky Boži. Dostal jsem se do neznámých končin, do východního Polska, na Volyn̆, do pěkné české obce Kupičov. Velice jsem si zamiloval tu obec $i$ ten lid. Nejbohatši byla pro mne doba druhé světové války, tehdy se na mne vztahovala slova z Bible: ,Pouštěj chléb svioj po vodě, po mnohých dnech najdeš jej. “" (Kazatel 11,1).9 Druhá světová válka byla na Volyni obzvlášt’ složitá - přechod front, národnostní konflikty mezi Poláky a Ukrajinci, pronásledování Židů, řádění banderovců... Fara Jana Jelínka se stala v této těžké a složité době útočištěm pro všechny pronásledované, at' byli jakéhokoliv vyznání, národnosti či přesvědčení. Jan Jelínek

4 Jan JELÍNEK, Pouštěj chléb svưj po vodě. Mé vzpomínky, B. m. 2003, s. 32. Tuto knihu využil polský spisovatel Witold Szabłowski při psaní publikace Spravedliví zrádci - sousedé z Volyně, která v českém překladu vyšla v roce 2018. Viz Josef ČÁP, Pocta manželi̊m Jelínkovým, Informační věstník zapsaného spolku Exulant, 2020, č. 49, s. 6.

J. JELÍNEK, Pouštěj chléb svi̊j po vodě, s. 53.

Po první světové válce tato část dnešní Ukrajiny připadla Polsku.

K historii obce Kupičov Český srv. Václav KYTL - Václav ZÁPOTOCKÝ - Miloslava ŽÁKOVÁ, Kupičov. Jak nám o něm vyprávěli, Fakta a jména, Praha 1997 a Obrázky z Kupičova (vzpomínky pamětníků zpracovali a uspořádali Václav Kytl, Miloslava Žáková). B. m. 2000.

8 Srv. J. JELÍNEK, Pouštěj chléb svi̊j po vodě. Publikace je uložena v osobním archivu Jana Jelínka. Viz Národní archiv (dále jen NA), fond (dále jen f.), Jan Jelínek, nezprac., ka 5.

J. JELÍNEK, Pouštěj chléb svi̊j po vodè, s. 3. 


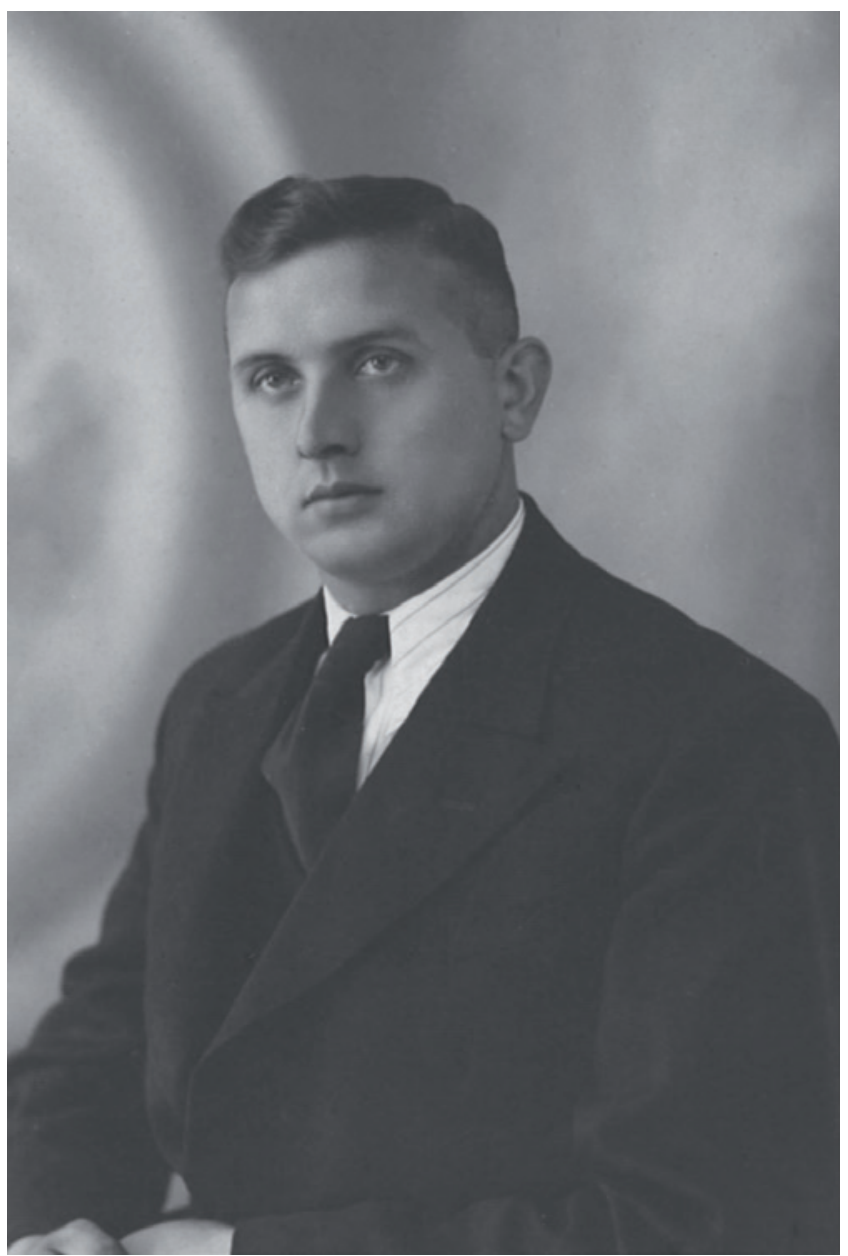

Obr. 3. Portrétní fotografie z doby působení Jana Jelínka v Kupičově Českém (asi rok 1937). NA f. Jan Jelínek, nezpracováno.

ukrýval Židy před Němci, Poláky před banderovci, Ukrajince před Rusy.

Pomoc potřebným začal Jelínek poskytovat prakticky ihned po vypuknutí druhé světové války. Od roku 1942 mu velmi aktivně pomáhala jeho manželka Anna, která mu byla, nejen v těchto těžkých dobách, oporou. Když Německo napadlo v záŕí 1939 Polsko, začaly se z nacisty obsazených území přesunovat do tehdejšího východního Polska (dnes oblast Ukrajiny) skupiny uprchlíků. Tehdy Jelínek poskytl ubytování židovské rodině Fischerových z Českého Těšína a početné rodině Veselých z Varšavy. ${ }^{10}$ Rodina Františka Veselého u něj bydlela od 3. zárí 1939 do 26. října. 1939. ${ }^{11} \mathrm{~V}$ tomto období materiálně pomáhal také skupině československých letců zařazených do polského letectva, kterým se po pádu Polska podařilo dostat na území okupované Sovětským svazem. Těm Jelínkovi poskytli nejen potraviny, ale také šatstvo. ${ }^{12}$ Skupina letců pod vedením štábního kapitána Štěpánka později z Kupičova odjela do Českého Kvasilova, kde se spojila s tzv. Kvasilovskou skupinou. ${ }^{13}$ Setkání s krajany z vlasti svých předků patřilo mezi radostné okamžiky, kterým ale doba př́iliš neprála. Polskou část Volyně, kam patřil rovněž Kupičov, obsadila $\mathrm{v}$ rámci paktu Ribbentrop-Molotov Rudá armáda. Jakmile se situace stabilizovala, začali Sověti na nově získaném území s kolektivizací zemědělství a s vyvážením bohatých sedláků či podnikatelů na Sibiř. Volyn̆ patřila pod správu Sovětského svazu až do roku 1941, kdy území obsadili nacisté v rámci tažení proti SSSR.

Jan Jelínek poskytoval pomoc všem, kdo ji potřebovali v období od napadení SSSR v červenci 1941 nacistickým Německem až do osvobození Volyně jednotkami Rudé armády na jaře 1944. Několik měsíců poté, co Němci v roce 1941 obsadili území Volyně, začali s vyvražd’ováním židovského obyvatelstva. Pronásledovaní Židé hledali záchranu u svých spoluobčanů. Nacházeli ji také u Čechů. Díky Jiřímu Hofmanovi jsou známa jména více než 230 Židů, na jejichž záchraně se podílelo více než 70 českých rodin. ${ }^{14}$ Ty riskovaly životy zachráněných i své. Sedm volyňských českých rodin obdrželo čestný titul Chasidej umot haolam (Spravedlivý mezi národy) a medaili od památníku Yad Vashem (památník Hrdinům a obětem holokaustu) v Jeruzalémě. Židům pomáhal rovněž Jan Jelínek. Na faře našli úkryt a pomoc mj. židovští manželé Fronkovi. Jan Jelínek na ně později zavzpomínal: ,[Fronek, pozn. aut.] měl slovenské doklady a já jsem mu shánél potvrzení na úř́adě, ale tam mi řekli, že jsem již dávno mèl přijít o hlavu a potvrzení jsem nedostal. Chtěl jsem zubaře Fronka převést [...] do bezpeči. " ${ }^{15}$ Fronka chtěl Jelínek odvést do vesnice Stávky. To se mu ale bohužel nepodařilo a rodina byla dle Jelínkových vzpomínek později odeslána na nucené práce do Německa. ${ }^{16}$ Pomáhal také židovským obyvatelům kovelského ghetta, kam vozil potraviny, přestože mu hrozilo nebezpečí, že bude zajat německými hlídkami. Sám na to vzpomíná: ,,Z Kovle mi někteř́ psali, abych se nad nimi smiloval a poslal jim nějaké živobytí. Koupil jsem brambory, mouku, kroupy, sádlo, máslo i dalšsi věci a jel do Kovle. Tam nás zastavila německá hlídka. Na dotaz, co vezu, jsem řekl, že kontingent. Němec to spolkl a já št́astnè tento proviant zavezl do ghetta. "17

Situace na Volyni se postupně stávala stále složitější. Původní předpoklady, že nacisté umožní Ukrajincům vlastní stát, se ukázaly jako liché. Z ukrajinských pomocníků nacistů (především ukrajinské policie) časem vznikla Ukrajinská povstalecká armáda, která je známa rovněž pod zkratkou (UPA) nebo označením banderovci. Jejich cílem ale nebyl

10 Jednalo se celkem o devět osob. Viz Vojenský ústřední archiv-vojenský historický archiv (dále jen VÚA-VHA), Sbírka dokumentace oddělení pro vydávání osvědčení MO ČR, č. j. 025188/48, spis Jana Jelínka, s. 18.

11 VÚA-VHA, Sbírka dokumentace oddělení pro vydávání osvědčení MO ČR, č. j. 025188/48, Spis Jana Jelínka, s. 18.

12 Tamtéž.

13 Na území dnešní západní Ukrajiny (především v prostoru Volyně) působila po obsazení SSSR v období od 21. září 1939 do 26. března 1940 „Skupina př́slušníků bývalé čs. legie v Kvasilově Českém“, která je známá pod označením Kvasilovská skupina. Jednalo se o československé vojáky, jejich rodiny a rodiny pracovníků Krakovského konzulátu, kteří se ve válečném chaosu v záríí 1939 ztratili a nemohli najít Československou vojenskou skupinu. Postupně vytvořili organizovanou skupinu, čítající v době odjezdu z Volyně na sto padesát osob, včetně sedmnácti žen.

14 Jiř́i HOFMAN - Václav ŠIRC - Jaroslav VACULÍK, Volyňšti Češi v prvním a druhém odboji, Praha 2004, s. 257-359. Jana Jelínka jako zachránce Židů Jiř́ Hofman v seznamu neuvádí.

15 Srv. J. JELÍNEK, Pouštěj chléb svůj po vodě, s. 105.

16 Tamtéž, s. 108.

17 Tamtéž, s. 106. 


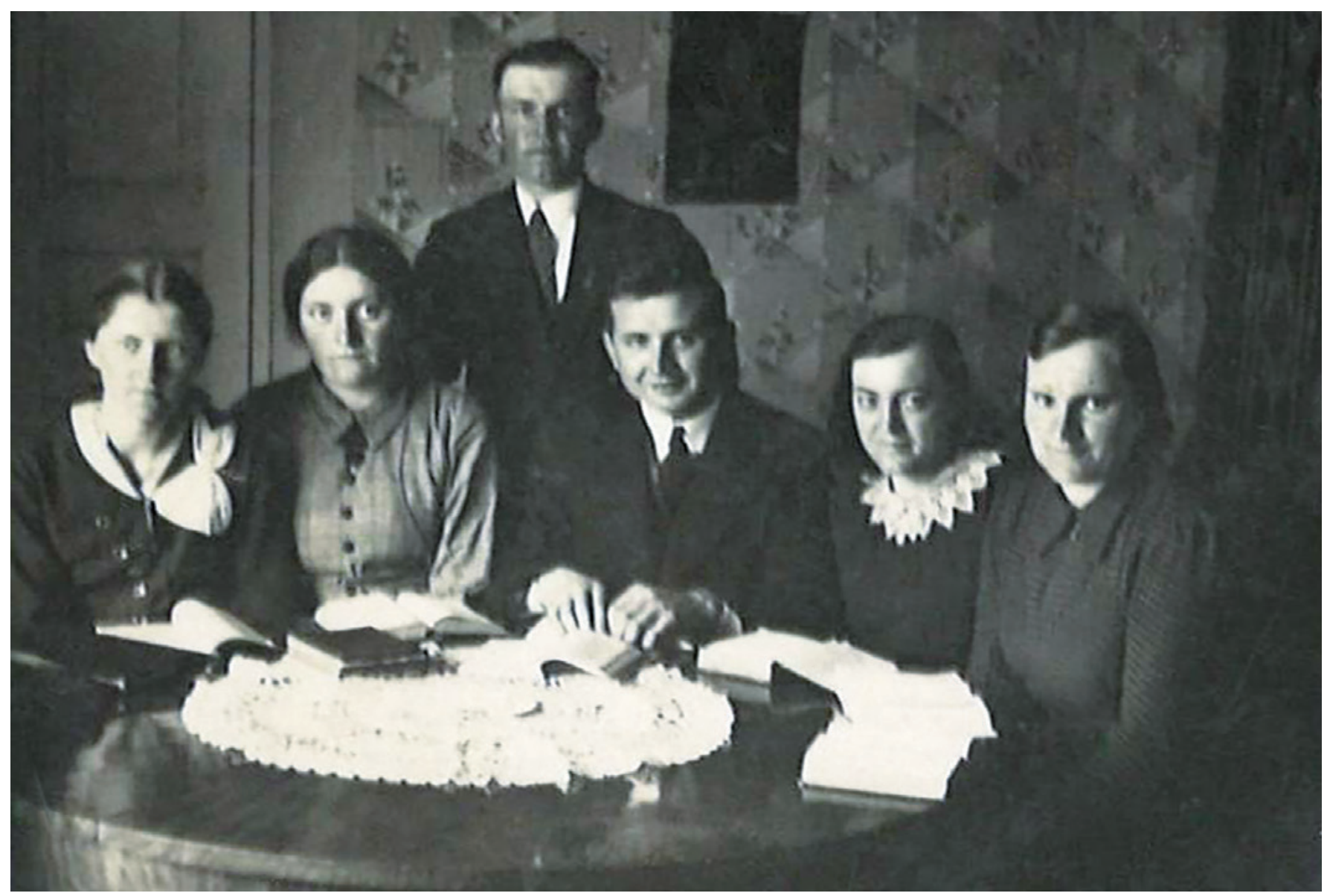

Obr. 4. Přípravka učitelů nedělní školy v Kupičově. NA f. Jan Jelínek, nezpracováno.

pouze boj proti nacistickým okupantům a sovětskému režimu, ale snažili se také o etnickou čistotu své vlasti. Od podzimu 1942 začali vyvražd'ovat Poláky. Například na Velikonoce roku 1943 připravili banderovci koordinovanou akci, při které obklíčili desítky kostelů a zavraždili věřící shromážděné k bohoslužbám. Přeživší Poláci utíkali v noci tajně do Kupičova. Češi je schovávali na půdách a ve stodolách. Ukryli jich prý přes 400. Nejvíce Poláků našlo útočiště u Bohuslava Balouna, Václava Žitného a také u Jelínků na evangelické faře. Prokazatelně Jelínek ukrýval dvě třičlenné rodiny Siekerských a v pramenech blíže nespecifikovanou rodinu ředitele školy, kterým hrozila smrt od banderovců. ${ }^{18}$ Ukrývání Poláků mělo svá rizika. Těm, kteří jim pomáhali, hrozila od banderovců v př́padě odhalení smrt. Také na faru $\mathrm{k}$ Jelínkům přišli jednou v noci banderovci hledat Poláky. Poseděli s Jelínkovými a pak řekli, že se podívají po domě. Jan Jelínek byl strachy ochromen. Na půdě totiž bylo pět nebo šest Poláků. Přesto vzal za kliku dveří a řekl, at' jdou dům zkontrolovat. Banderovci mu uvěřili a odešli. ${ }^{19}$ V Černilově banderovci napadli rodinu římskokatolického ministranta Zubkiewicze. Jeho manželku a jeho dvě dcery zavraždili. Syn utekl a těžce raněný otec předstíral, že je mrtev. Podařilo se mu dostat do Kupičova. Jeho další osudy popsal Jan Jelínek takto: ,, Soused Vrla nám sdělil, že raněný je u nás v obci. Ležel u Kozliku ve stodole a byl na pokraji smrti. Žádal jsem felčara p. Niemoškalenka, aby šel se mnou raněného Zubkiewicze ošetřit. Zeptal se mě: ,Je to Polák?' ,Ano, ‘ rekl jsem. Odpověděl: ,Bojím se svých spoluobčanů-ukrajinských banderovců. Kdyby se to dozvěděli, zabijou mě. 'Vzal jsem to tedy na sebe: ,Mưžete řict, že jsem vás přinutil, bude to tudiž moje vina. 'Měl jsem silnou víru a věril jsem, že mne Pán Bůh ochrání. Raněnému jsme rozřizli košili a objevila se rána jako dlan̆. Okolí zachvácené gangrénou a spousta červì. Lékař ho ošetřil, oblékli jsme ho a já jsem jej pak vedl přes dvůr Šulců k nám na faru. Tři týdny u nás ležel. Až po návratu Němců se tu setkal se svým synem. Radost z tohoto setkáni byla pro nás největši odměnou. Navštívil nás také katolický kněz a jménem své církve i polského národa nám děkoval za záchranu Poláka. "20

Pomoc Jelínek poskytl také osobám, které pronásledovali Poláci. Jednalo se většinou o Ukrajince, občany, kterým se Poláci mstili za vraždy spáchané banderovci na Polácích. Ukryl paní Šolomyckou se synem, které chtěli zavraždit proto, že její manžel byl banderovec. Před Poláky ukrýval také po dobu šesti měsícủ ${ }^{21}$ čtyřčlennou ukrajinskou rodinu Luciukových. ${ }^{22}$

18 NA, f. Jan Jelínek, nezprac., ka 1, Pplk. v. v. Jan Jelínek. Životopis a stručná charakteristika, s. 1.

19 Srv. J. JELÍNEK, Pouštěj chléb svưj po vodě, s. 108.

20 Tamtéž.

21 VÚA-VHA, Sbírka dokumentace oddělení pro vydávání osvědčení MO ČR, č. j. 02518848/, Spis Jana Jelínka, s. 18.

22 NA, f. Jan Jelínek, nezprac., ka 1, Pplk. v. v. Jan Jelínek. Životopis a stručná charakteristika, s. 2. 
Jan Jelínek byl svědkem nacistického řádění, které se nevyhnulo ani českým osadám. Český Malín zničili nacisté hroznějším způsobem než Lidice. Upálili a povraždili zde celkem 374 osob české národnosti, z toho 105 dětí do čtrnácti let. Bezdůvodně postř́leli třetinu občanů další obce Michny-Sergejevky. Přičteme-li k těmto obětem Čechy upálené zaživa a zavražděné v dalších obcích, pak celkové oběti nacistického běsnění představují více než 466 osob. ${ }^{23}$ Podobný osud připravili nacisté mnoha ukrajinským vesnicím. Přestože Jelínek věděl, jakých zločinů se Němci dopouštějí, zachránil svým svědectvím dokonce dva německé vojáky zadržené banderovci, kteří se vydávali za Čechy. „,Vzdali se jim [banderovcům, pozn. aut.] dva němečtí vojáci, kteři prohlašují, že jsou Čechy. Banderovci chtéli zjistit pravdu. Jeli jsme tedy s Bohušem Ledvinou a starostou Kučerou. Před cestou jsem prosil Pána Boha, abych mohl $v$ dobré věci i lhát. Dorazili jsme do banderovského štábu ve Sviňarském lese. Předvedli nám dva vojáky; bylo na nich hned vidět, že jsou to Němci. Jeden z Mostu, druhý Videňák. Česky mluvili málo, ale domluvili jsme se. Řekl jsem jim, aby všude řikali, že jsou Češi. Po půl hodině jsem Banderovcưm sdělil, že jsme si dobře ověrili, že zajatci jsou Češi. Tak jsme těm dvěma zachránili život a mohli jsme odjet. "24 Celkem Jan Jelínek prokazatelně pomohl v průběhu války 42 osobám, počet zachráněných však bude jistě vyšší. ${ }^{25}$

Jelínek byl zapojený do činnosti kupičovské domobrany, jejíž akce byly namířeny na obranu proti banderovcům. Podílel se také na budování obranných postavení a zátarasů kolem obce. Kupičovští totiž uzavřeli dohodu s 27. volyňskou divizí Armii Krajowej. ${ }^{26}$ Společně s Poláky se pak bránili několika útokům banderovců. Ten největší podnikli dne 22. listopadu 1943, kdy na obec neúspěšně zaútočilo několik tisíc banderovců s několika minomety, protitankovými děly. Jan Jelínek jako jeden z mála v Kupičově vlastnil rozhlasový přijímač, a tak zachycoval nejnovější zprávy o situaci na frontách a neváhal je dál šírit. Při poslechu rozhlasu se na faře setkávalo několik osob, které později vytvořily ilegální organizaci Aktiv. ${ }^{27}$ Sám Jelínek se ve svých vzpomínkách vyjádřil ke vzniku a činnosti organizace Aktiv těmito slovy: „Již v roce 1942 na podzim při tajném poslechu rozhlasu jsme s některými krajany uvažovali o odbojové organizaci. Toto se uskutečnilo v lednu 1943 na evangelické faře, kdy jsme organizovali skupinu odboje v počtu 7 osob tak zvaný Aktiv kupičovský. Vedoucím organizace byl zvolen Bohuslav Ledvina. Prvním naším úkolem bylo informovat naši mládež i dospělé

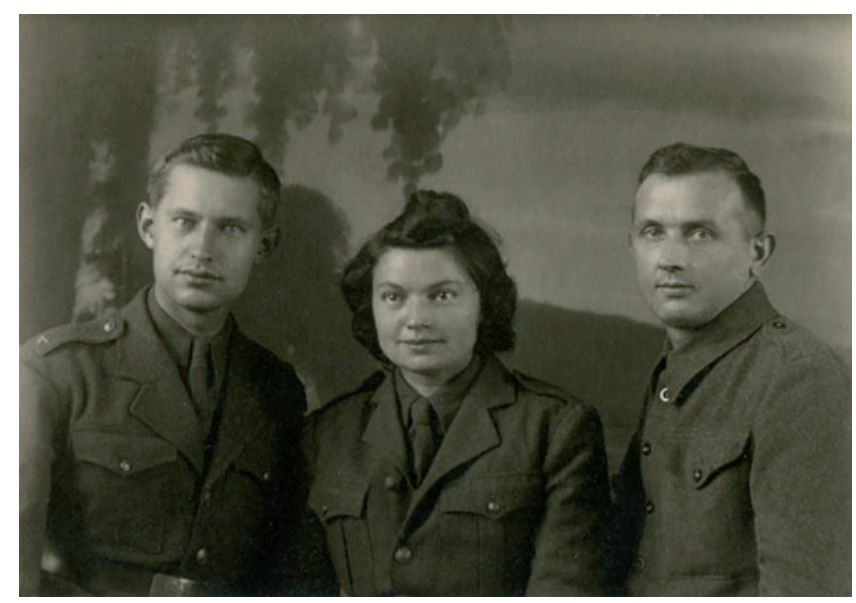

Obr. 5. Manželé Jelínkovi v době svého působení v 1. československém armádním sboru v SSSR na fotografii z roku 1944 spolu s bratrancem Anny Jelínkové Antonínem Blažkem (na snímku první zleva). NA f. Jan Jelínek, nezpracováno.

o bojich, jak na západní, tak i na východni frontě, nebot' německé zprávy nebyly věrohodné. Dalším naším úkolem bylo zachránit naši mládež před odvodem do Německa na práci. Vždyt' jsme počitali, že jednou vstoupi do československé jednotky, která se tvořila v Buzuluku. Poslech zpráv od spojencù z Anglie a z Moskvy byl velmi nebezpečný. Nebot' nejenom Němci, ale i ukrajinská milice, která jim přisluhovala, byla velmi nebezpečná a ohrožovala každého podezřelého. Poslech rozhlasu byl již na více mistech, a to u Stanislava Tošnera, Josefa Fialy a jinde. Dalším úkolem organizace bylo shánét zbraně a náboje. I to se povedlo, a to koupí za slaninu od německých dezertérů, trofeji a od polských partyzánů. Z jara $1943^{28}$ o Velikonočním ponděli utekla ukrajinská milice do lesů. Krátce nato tito banderovci verbovali naše krejčí, a obuvníky do lesů, aby jim šili obleky a zhotovovali obuv. Náš Aktiv se proti tomuto postavil záporně z di̊vodů: a) banderovci perzekvovali sovètské lidi, kteři zůstali na Volyni, tím a jinými způsoby bojovali proti Sovétskému svazu, b) pálili polské obce a krutě vraždili jejich obyvatele c) usmrtili některé naše krajany (kolem 15 osob). "29

Manželé Jelínkovi bránili předávání dodávek obilí a dobytka německé armádě. ${ }^{30}$ Č́st obilí (prý 700 kilogramů), ukryl Jelínek před Němci na půdě fary. Po osvobození oblasti obilí věnoval Rudé armádě. ${ }^{31}$

23 Jiř́i HOFMAN - Václav ŠIRC - Jaroslav VACULÍK, Volyňšti Češi v prvním a druhém odboji, s. 287.

24 J. JELÍNEK, Pouštěj chléb svioj po vodě, s. 114.

25 Údaj získán z životopisu Jana Jelínka součtem počtu osob, kterým Jan Jelínek pomohl. Viz NA, f. Jan Jelínek, nezprac., ka 1, Pplk. v. v. Jan Jelínek - životopis a stručná charakteristika, s. 1-2.

26 Polská partyzánská organizace podléhající londýnské exilové vládě.

27 Jan Jelínek v žádosti o vydání osvědčení dle paragrafu 255/1946 Sb., uvádí, že se kromě jeho osoby jednalo o Alexandra Ducháčka, Václava Kožnara, Stanislava Tošnera, Bohuslava Ledvinu, Jaroslava Novotného, Antonína Řepku. Viz VÚA-VHA, Sbírka dokumentace oddělení pro vydávání osvědčení MO ČR, č. j. 025188/48, Spis Jana Jelínka, s. 10. PhDr. Miloslava Žáková upřesnila, že se jednalo o osoby, které měly výborné organizační schopnosti a byly velmi aktivní zejména při organizování obrany proti banderovcům. Název Aktiv podle ní vznikl až po válce. $Z$ rozhovoru Romana Štéra s PhDr. Miloslavou Žákovou ze dne 18. 2. 2020.

28 Zde Jan Jelínek uvádí nesprávné datum. K popisovaným událostem došlo o rok dříve.

29 NA, f. Jan Jelínek, nezprac., ka 1, Jan Jelínek: Moje odbojová činnost, B. d., 1 s.

30 Když Němci rekvírovali dobytek, podařilo se Janu Jelínkovi spolu s jedním spoluobčanem odvést z ohrady, zatím co Jelínkova manželka hovořila s německým důstojníkem, celkem patnáct kusů hovězího dobytka. Němci mnohdy odvedli hospodárưm jejich poslední krávu, která živila celou rodinu. Díky zásahu Jana Jelínka nepřišly rodiny o svou obživu. J. JELÍNEK, Pouštěj chléb svioij po vodě, s. 112

31 VÚA-VHA, Sbírka dokumentace oddělení pro vydávání osvědčení MO ČR, č. j. 02518848/, Spis Jana Jelínka, s. 18. 


\section{V čs. vojenské jednotce v SSSR}

Když se na jaře 1944 blížila fronta (byla mezi Kupičovem a Luckem), Jan Jelínek se stal členem delegace kupičovských mužů ${ }^{32}$ která se dne 14. dubna vypravila za frontu, do osvobozeného města Luck, aby nabídla štábu 1. čs. samostatné brigády v SSSR vedeným brigádním generálem Ludvíkem Svobodou vstup 237 kupičovských obyvatel do jejich řad. Při zpáteční cestě se Jan Jelínek nakazil břišním tyfem a po vyléčení, přestože byl jako duchovní od vojenské služby povinnosti osvobozen, vstoupil i s manželkou Annou jako dobrovolník do tehdy se tvořícího 1 . čs. armádního sboru v SSSR. Nejprve byli oba zařazeni do náhradního pluku, kde působili dle vzpomínek Jana Jelínka jako písaři ${ }^{33}$ Pak byli Jelínkovi přemístěni k 5. čs. dělostřeleckému pluku, jehož velitelem byl Alois Boček a kde Jelínek dostal za úkol správu zbrojního skladu. ${ }^{34}$ Manželka působila na velitelství pluku jako spojka mezi čs. a sovětským štábem. Manželé Jelínkovi se také účastnili bojů u Dukly a osvobozování Československa. Ještě před skončením války absolvoval v Popradě důstojnickou školu.

Jana Jelínka za jeho činnost v 1. čs. armádním sboru vyznamenali bezprostředně po válce Československým válečným kř́̌žem 1939, Československou vojenskou medailí Za zásluhy II. stupně, Pamětní medailí československé armády v zahraničí se štítkem SSSR, sovětskou medailí Za vítězství nad Německem, v padesátých letech získal ještě Dukelskou pamětní medaili. Později obdržel řadu pamětních medailí udělovaných při výročích ukončení druhé světové války, včetně vyznamenání některých organizací, kterých byl členem - Svazu protifašistických bojovníků a Konfederace politických vězňů ČR.

Po skončení války zůstává Jelínek nadále v armádě. Koncem června obsadil 5. čs. dělostřelecký pluk kasárna v Rakovníku, Jan Jelínek zde zastával funkci hospodáře proviantní služby a kromě toho měl na starosti proviantní sklad v Kolešovicích a zvěrolékařský sklad v Kněževsi. Koncem záŕí jsou Jelínkovi přmístěni ke Zvláštní vojenské skupině do Žatce, která měla na starost usídlení volyňských Čechů bývalých př́íslušníků 1 . čs. armádního sboru. ${ }^{35}$ Demobilizovali jej dne 25. listopadu 1946 v hodnosti poručíka hospodářské služby v záloze. ${ }^{36} \mathrm{~V}$ druhé polovině devadesátých let minulého století jej několikrát mimořádně povýšili, ${ }^{37}$ a to až do hodnosti podplukovníka ve výslužbě, do které byl povýšen dnem 8. května 1997. ${ }^{38}$

\section{Ve vlasti předků}

Po demobilizaci se s manželkou usadili nakrátko v Žatci, brzy se však přestěhovali mezi kupičovské a zelovské krajany do Oráčova na Rakovnicku ${ }^{39}$ a Jan Jelínek opět začal působit jako českobratrský evangelický duchovní. Měl v duchovní správě rozsáhlé území Žluticka. V roce 1946 dokončil studium na gymnáziu a při své práci duchovního jako mimořádný posluchač studoval rovněž Husovu evangelickou bohosloveckou fakultu v Praze. ${ }^{40}$

V letech 1946-1948 pracoval také jako důvěrník Československého ústavu zahraničního. Pomáhal především při repatriaci krajanů z polského Zelova a z Volyně (Ukrajiny a SSSR). V této době Jan Jelínek zachránil nejméně deset ukrajinských emigrantů, kteří se báli vrátit do Sovětského svazu. Vystavil jim křestní listy s razítkem kupičovské farnosti, ${ }^{41}$ tím se $\mathrm{z}$ nich stali repatrianti z Volyně a s největší pravděpodobností je zachránil před gulagem. Sám Jelínek o tom píše ve svých vzpomínkách: „Abych se nyní po více než 55 letech přiznal, bylo více lidí, jimž jsem musel psát nové , kościelne 'rodné listy. Díky, že všechno nám na Volyni v Kupičově zničila Rudá armáda, ale razitko ,Kolegium kościelne ewangelicko-reformowanej parafii v Kupiczowie ‘ jsme vzali. Toto razitko zachránilo mnoho nešt’astných lidí před utrpením. Věřm, že v plné čistotě mohu před Pánem Bohem obstát. "42 Jak Jelínek zmiňoval v rozhovorech pro tisk, doklady nechával na sluníčku, aby vypadaly starší. Jelínek si byl velmi dobře vědom toho, co by následovalo, pokud by se o tomto počínání dozvěděly bezpečnostní složky

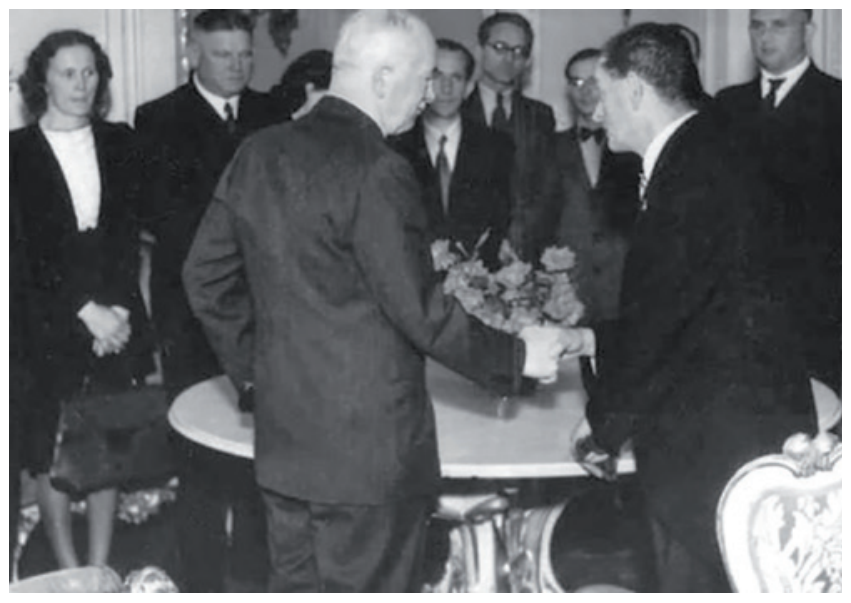

Obr. 6. Přijetí u prezidenta republiky Edvarda Beneše v roce 1946. NA f. Jan Jelínek, nezpracováno.

\footnotetext{
Delegaci tvořili Bohuslav Ledvina, Jan Jelínek, Jaroslav Židlický a Jaroslav Šebesta. Srv. Jan JELÍNEK, Pouštěj chléb svi̊j po vodě, s. 118.

Tamtéž, s. 125.

K historii jednotky srv. Milan KOPECKÝ, Československý sborový dělostřelecký pluk 5 (1944-1945), Praha 2012.

J. JELÍNEK, Pouštěj chléb svưj po vodě, s. 144.

36 VÚA-VHA, Sbírka dokumentace oddělení pro vydávání osvědčení MO ČR, č. j. 02518848/, Spis Jana Jelínka, s. 10.

37 Poprvé se tak stalo v roce 1995, kdy jej mimořádně povýšili do hodnosti kapitána ve výslužbě a podruhé v témže roce do hodnosti majora ve výslužbě. Jednalo se vždy o povýšení k výročí významných událostí druhé světové války. Srv. NA, f. Jan Jelínek, nezprac., ka 1, Výpisy z rozkazu ministra obrany ČR ze dne 13. 4. 1997 a 11. 10. 1995.

38 NA, f. Jan Jelínek, nezprac., ka 1, Výpis z rozkazu ministra obrany ČR ze dne 7. 4. 1997.

39 Podle záznamu v žádosti o vydání osvědčení dle paragrafu 255 se tak stalo na konci listopadu 1946. Viz VÚA-VHA, Sbírka dokumentace oddělení pro vydávání osvědčení MO ČR, č. j. 025188/48, Spis Jana Jelínka, s. 9.

40 V roce 1956 složil před Synodní radou farářskou zkoušku a zůstal činným farářem až do svého zatčení v roce 1958. Viz Národní archiv, f. Jan Jelínek, nezprac., ka 1. Vlastní životopis Jana Jelínka.

41 Razítko je nyní součástí osobního archivu Jana Jelínka.

42 J. JELÍNEK, Pouštěj chléb svioj po vodě, s. 159.
} 
komunistického režimu: ,Jsme rádi, že jsme pomohli a že se o tom nedozvédèli komunisté. To by bylo vězení, ne na dva roky, ale možná tak na deset rokủ i víc, týrání a bití. "“3

\section{Vězněm komunistického režimu}

Perzekuci, odsouzení a věznění ze strany minulého režimu však Jan Jelínek neunikl. Pro své otevřené názory se ocitl rovněž v hledáčku zájmu StB. Již v roce 1952 odmítl např. požadavek církevního tajemníka, aby přesvědčoval rolníky ke vstupu do JZD s tím, že to není úkol kazatele. V průběhu padesátých let byl StB několikrát vyšetřován, v roce 1952 se ho StB dokonce marně snažila přimět ke spolupráci. ${ }^{44}$ Nakonec byl však dne 10. 1. 1958 přece jen zatčen. ${ }^{45} \mathrm{StB}$ ho odvedla ze školy v Jesenici prímo z výuky náboženství. Důvodem $\mathrm{k}$ jeho zatčení bylo údajné ,vyvolávání nepřátelské nálady proti lidově demokratickému státnímu zř́zení $v$ ČSR a proti vymoženostem pracujícího lidu dosaženým při výstavbě socialismu". "Vyšetřovatelé StB Jana Jelínka obvinili, že ,, v době od r. 1952 až do současné doby na různých mistech v okrese Podbořany z nepřátelství k lidově demokratickému zrízení pronášel před rüznými osobami výroky, zpüsobilé vyvolat neprátelskou náladu proti republice, v úmyslu nepř́znivě ovlivnit jejich postoj vưči lidově demokratickému ř́du v ČSR a socialistické výstavbě, přičemž zneužival i důvěry, kterou měl jako duchovní mezi věř́cími “ ${ }^{47}$

Jelínek byl obviněný pro trestný čin pobuřování proti republice. ${ }^{48}$ Podle obvinění měl Jelínek rovněž , šiřit $i$ letáky tzv. lidové opozice a zprávy vysílané Svobodnou Evropou “" ${ }^{49}$ $\mathrm{V}$ domě manželů Jelínkových byla dne 9. 1. 1958 provedena domovní prohlídka, avšak vyšetřovatelé nenalezli žádné tiskoviny ani jiné písemné materiály, jejichž obsah by byl nepřátelský socialistickému zř́zení. Nalezli však mimo jiné cyklostylovaný dokument s názvem „Smysl života“, fotografie, kapesní kalendáře, slovníčky... ${ }^{50}$

Obžaloba ze smyšlených zločinů měla odstranit nepohodlnou autoritu. Tři měsíce a jeden týden strávil Jelínek ve vyšetřovací vazbě ve Vykmanově ${ }^{51}$ u Jáchymova. Takto na toto těžké období vzpomíná ve své knize: „Ve vazbě jsem byl sedmnáctkrát vyslýchán. ${ }^{52}$ V blizkosti mé cely byl výtah, a když jsem ho slyšel prijiždět, byl jsem velmi nervózní. Některý den mé vyslýchali čtyři hodiny, někdy i osm hodin. A stále totéž dokola. Měli 104 stran obžaloby; byl jsem, hrozný zločinec‘. Šestnáctý a sedmnáctý výslech byl již mírnější. "53 O strázních, které zde prožil, vypovídá i skutečnost, že zde zhubl patnáct kilogramů. Další tvrdé zkoušky osudu však měly teprve přijít.

V březnu 1958 byl Lidovým soudem v Podbořanech ${ }^{54}$ odsouzen za pobuřování proti republice, za údajný nesouhlas s kolektivizací a za smyšlené pobuřování proti zakládání JZD, ke dvěma letům odnětí svobody, zákazu činnosti duchovního na 5 let a k zákazu pobytu v celém Karlovarském kraji a přiléhajících okresech na 5 let. Soud Jelínka uznal vinným, ,že od roku 1952 do konce roku 1957 v Podbořanech, v Oráčově a na jiných mistech okresu Podbořany před občany Miroslavem Majerem, Adolfem Filipi, Karlem Slavíkem, Janem Lebedou, Václavem Mlejnkem, z nepřátelství k našemu lidově demokratickému zřizení pronášel výroky neprátelské republice a její socialistické výstavbě a rozšiřoval obsah neprátelských letáků, aby tak ovlivnil politické smýšleni uvedených občanů i jiných osob v neprospěch lidově demokratického státního zrrizeni " ${ }^{55}$ Jan Jelínek verdikt přijal s pohnutím: „Byl jsem velice dojat, když jsem viděl, jak moji členové sboru plakali. I mou tvár̆ polily slzy. "56 Předsedou senátu byl JUDr. Vladimír Pračke, obžalobu podal okresní

43 Tamtéž, s. 158.

44 Jan Jelínek v dokumentu ze dne 10. 3. 1969 píše: „, V době druhé světové války jsem se účastnil bojů ve východní armádě jako voják a di̊stojník čsl. samostatné jednotky v SSSR. Byl jsem vyznamenán medailí druhého stupně za zásluhy a Československým válečným křižem 1939. Patrně z toho důvodu v roce 1952 (přesně si nevzpomínám na datum) mne po celý den přemlouvali př́slušníci StB v Podbořanech, abych s nimi spolupracoval. Když jsem to odmitl, byl jsem dán pod dozor řediteli devitileté školy p. Šnajdrovi, který v té době pưsobil ve Valči. Jmenovaný mi dosvědčí že StB jej vyzvala, aby o mně podával nepríznivé zprávy“. In: NA, f. Jan Jelínek, nezpracováno, ka 1, Vzpomínky Jana Jelínka ze dne 10.3 .1969$.

45 Archiv bezpečnostních složek (dále jen ABS), Sbírka Správa vyšetřování StB - vyšetřovací spisy (V), arch. j. V-3613 MV. Osobní vyšetřovací svazek č. 481 proti Janu Jelínkovi. Osobní svazek archivovaný dne 17. 4. 1958 Okresním oddělením Ministerstva vnitra v Podbořanech arch. č. 463, který nesl krycí název „Faráŕ“, byl dne 15. 2. 1960 předán Krajské správě Ministerstva vnitra Praha a uložen pod arch. č. 43688 MV, byl dne 20. 10. 1985 zničen.

46 ABS, Sbírka Správa vyšetřování StB - vyšetřovací spisy (V), arch. j. V-3613 MV, Osobní vyšetřovací svazek č. 481 proti Janu Jelínkovi. Usnesení Krajské správy ministerstva vnitra Karlovy Vary k zahájení vyšetřování podle $§ 176$ tr. ř. ze dne 3. 1. 1958.

47 ABS, Sbírka Správa vyšetřování StB - vyšetřovací spisy (V), arch. j. V-3613 MV, Osobní vyšetřovací svazek č. 481 proti Janu Jelínkovi, Usnesení Krajské správy ministerstva vnitra Karlovy Vary k zahájení vyšetřování podle $§ 176$ tr. ř. ze dne 10. 1. 1958.

48 Zákon č. 861950 / Sb. Trestní zákon: $\$ 811 /$ ) Kdo z neprátelství k lidově demokratickému řádu a) veřejně nebo nejméně dvě osoby pobuřuje proti republice, proti její samostatnosti, lidově demokratickému státnímu zř́zení nebo společenskému rádu, proti vymoženostem pracujícího lidu dosaženým při výstavbě socialismu, proti územní celistvosti nebo obranyschopnosti republiky, nebo b) úmyslně umožňuje nebo usnadňuje šíření takového pobuřujícího projevu, bude potrestán odnětím svobody na tři měsíce až tři léta.

49 ABS, Sbírka Správa vyšetřování StB - vyšetřovací spisy (V), arch. j. V-3613 MV, Osobní vyšetřovací svazek č. 481 proti Janu Jelínkovi, Usnesení Krajské prokuratury v Karlových Varech ze dne 13. 1. 1958 proti stížnosti Jana Jelínka na usnesení vyšetřovatele.

50 ABS, Sbírka Správa vyšetřování StB - vyšetřovací spisy (V), arch. j. V-3613 MV, Osobní vyšetřovací svazek č. 481 proti Janu Jelínkovi, Protokol o provedení domovní prohlídky ze dne 9. 1. 1958.

51 Vazba trvala od 13. 1. do 31. 3. 1958. Viz ABS, Sbírka Správa vyšetřování StB - vyšetřovací spisy (V), arch. j. V-3613 MV·Potvrzení o započítání doby vazby Jana Jelínka do délky trestu In: Osobní vyšetřovací svazek č. 481 proti Janu Jelínkovi.

52 ABS, Sbírka Správa vyšetřování StB - vyšetřovací spisy (V), arch. j. V-3613 MV, Osobní vyšetřovací svazek č. 481 proti Janu Jelínkovi, Protokoly z výslechů Jana Jelínka.

53 J. JELÍNEK, Pouštěj chléb svi̊j po vodě, s. 180.

54 ABS, Sbírka Správa vyšetřování StB - vyšetřovací spisy (V), arch. j. V-3613 MV, Osobní vyšetřovací svazek č. 481 proti Janu Jelínkovi, Obžaloba Jana Jelínka ze dne 19. 2. 1958 a Protokol o hlavním líčení proti Janu Jelínkovi u Lidového soudu v Podbořanech ze dne 4. 3. 1958. Rozsudek Lidového soudu v Podbořanech ze dne 5. 3. 1958 byl potvrzen krajským soudem v Karlových Varech dne 31. 3. 1958. Viz NA, f. Jan Jelínek, nezprac., ka 1, Rozsudek krajského soudu v Karlových Varech nad Janem Jelínkem ze dne 31. 3. 1958.

55 ABS, Sbírka Správa vyšetřování StB - vyšetřovací spisy (V), arch. j. V-3613 MV, Osobní vyšetřovací svazek č. 481 proti Janu Jelínkovi, Rozsudek Lidového soudu v Podbořanech ze dne 5. 3. 1958.

56 J. JELÍNEK, Pouštěj chléb svůj po vodě, s. 182. 


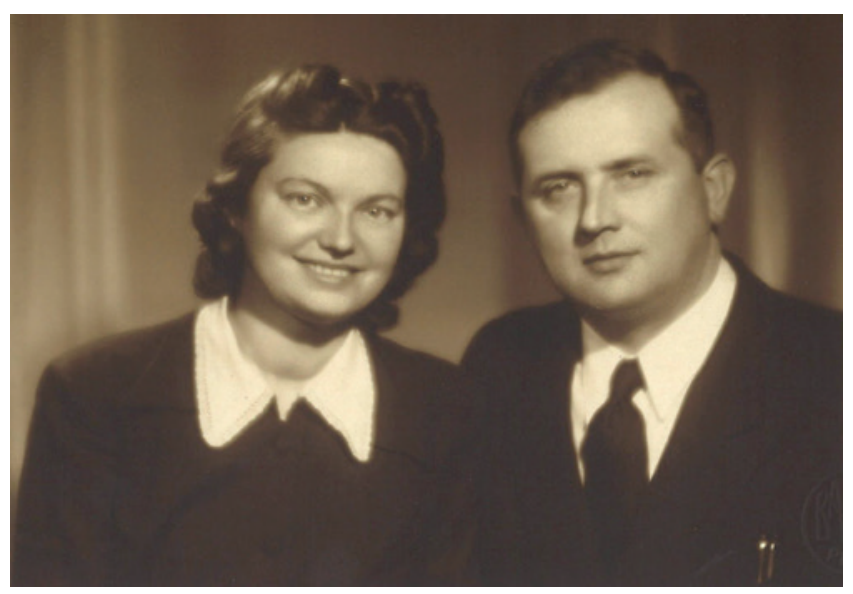

Obr. 7. Manželé Jelínkovi v únoru 1951. NA f. Jan Jelínek, nezpracováno.

prokurátor v Podbořanech Slavomil Henryk. Jana Jelínka obhajoval JUDr. Jan Lachman. ${ }^{57}$ Trest si odpykal v nápravném pracovním táboře ve Rtyni v Podkrkonoší, kde pracoval v dole Zdeněk Nejedlý 2.

Manželka Anna Jelínková se dne 1. 6. 1958 obrátila s prosbou o propuštění svého manžela na prezidenta republiky Antonína Novotného. Ve svém dopise mimo jiné pochybuje o hodnověrnosti svědků, kteří ve vykonstruovaném procesu svědčili proti Janu Jelínkovi, a snaží se pochopit motivy jejich jednání: „Domnívám se, že tito svědci-učitelé mají osobní zášt’ vióč manželovi, jelikož kdyby byli opravdu socialistického smýšlení, byli by věc hlásili dřive. Tato nedorozumění vznikla kvůli vyučování náboženství, které manžel jakožto farár na školách vyučoval, a které mu tito učitelé všelijak brzdili a ztěžovali. Když se dovolával svého práva, pomstili se na něm. Pročv jiných školách vycházel dobře a učil prece $v$ tolika školách. "58 Její prosbě však prezident republiky nevyhověl.

Manželům Jelínkovým se dostávalo v těchto těžkých dobách podpory od jejich nejbližších, od řady prrátel a spolupracovníků. V osobním fondu Jana Jelínka se mj. dochoval dopis adresovaný Anně Jelínkové od Jakuba S. Trojana, ${ }^{59}$ někdejšího faráře Českobratrské církve evangelické ve Kdyni na Šumavě, v němž paní Jelínkové vyjadřuje podporu: „přijměte laskavě $i$ ode mne slova povzbuzení a potěšení. Jistě neni lehké snášet to, do čeho jste byla v těchto mésících postavena. I sbor pocití citelně neprítomnost Vašeho manžela. Snad je nám všem přece dáno, vyhližet skrze temné chvíle nadějně kupředu. "60

O pokoře, se kterou přijal i tuto zkoušku, kterou mu život přichystal, vypovídají dopisy, které psal manželce z vězení: „,Jsem zde plně spokojen, dost stravy, volna i vycházek.
Jedno mi nejde $k$ duhu, to je velké chladno. Takové jako na Jáchymovsku, proto stále ještě topíme. " 61 Ve stejném dopise dále píše: „,Také jsem si již prohližel pracoviště v podzemí. Ponejprv je to dost strašné, ale myslím, že si zvyknu. " "J2 Jan Jelínek si na těžkou práci v dole zvykl. A přestože při ní utrpěl těžký úraz páteře, na osud nikdy nežehral. Jako by jeho životním krédem byla slova, která si zapsal v roce 1959 na poslední stránky v kapesním kalendáři:

„At’ je tvůj osud jakýkoli,
jej klidně vždycky nes.
Ten zvítězí, kdo nepovolí,
a ztracen ten, kdo kles.
A máš-li smutek,
slovem ani nevyzrad'
nikdy jej,
a máš-li štěstí, plnou dlaní
je světu rozdávej. "63

Když se v roce 1969 Jelínek vrací ve vzpomínkách k těžkým dobám a $\mathrm{k}$ samotnému vykonstruovanému procesu, píše tato slova: „Svédkové uvedeni v rozsudku, p. Slavík, Filipi, Majer, Mlejnek a Lebeda měli zřejmě týž úkol jako Šnajdr [StB jej vyzvala, aby o J. Jelínkovi podával nepříznivé zprávy - pozn. aut.], aby mne pozorovali. Když za pět let proti mnè nic konkrétniho nemohli uvést, vyprovokovávali se mnou rozhovory sami. Pomlouvali StB, stranu, a zvláště vyprovokovávali po událostech v Mad'arsku. Jakého charakteru to byli svědkové, vyplývá z toho, že svědek Slavik byl za defraudaci odsouzen na 14 let. Svědek Mlejnek na 2 roky za zneuživáni školních dětí a svědek Majer byl ze školni služby propuštěn jako nevhodný pro výchovu mládeže. Prokurátor a soud nepřipustili svědka Viléma Dedeciuse, předsedu JZD ve Valči, poněvadž mél dosvědčit pravý opak toho, co vypovídali svědkové Mlejnek, Majer a Slavík. Méně závažné výpovědi ostatnich svědki podle mého přesvědčeni byly vynuceny. Z uvedeného vyplývá, že proces proti mně byl uměle vykonstruován, a to zvláště proto, že jsem svědomitě zastával úrad a postavení českobratrského evangelického faráre. " 64

\section{Završení věrné služby Bohu i lidem}

Jan Jelínek se soudní rehabilitace dočkal až v roce $1990{ }^{65}$ Ministerstvo spravedlnosti ČR pak Janu Jelínkovi přiznalo nárok na odškodnění podle zákona číslo 119/1990 Sb. ${ }^{66}$

Po odpykání trestu se do Oráčova však nesměl vrátit. $\mathrm{S}$ pomocí př́átel si našel práci $\mathrm{v}$ Praze $\mathrm{v}$ podniku Barvy a laky, kde pracoval jako dělník až do svého odchodu do důchodu v roce 1972. Do Oráčova se vrátil teprve po svém odchodu do důchodu.

\footnotetext{
57 ABS, Sbírka Správa vyšetřování StB - vyšetřovací spisy (V), arch. j. V-3613 MV, Osobní vyšetřovací svazek č. 481 proti Janu Jelínkovi, Obžaloba Jana Jelínka ze dne 19. 2. 1958 a Protokol o hlavním líčení proti Janu Jelínkovi u Lidového soudu v Podbořanech ze dne 4. 3. 1958.

58 NA, f. Jan Jelínek, nezprac., ka 1, Dopis Anny Jelínkové prezidentu republiky Antonínovi Novotnému ze dne 1. 6. 1958. V Archivu Kanceláře prezidenta republiky se žádost Anny Jelínkové nenachází.

59 Jakub S. Trojan (1927), český teolog, bývalý děkan Evangelické teologické fakulty Univerzity Karlovy.

60 NA, f. Jan Jelínek, nezprac., ka 1, Dopis Jakuba S. Trojana Anně Jelínkové ze dne 29. dubna 1958.

${ }_{61}$ NA, f. Jan Jelínek, nezprac., ka 1, Dopis Jana Jelínka adresovaný manželce Anně ze dne 27. 4. 1958.

62 Tamtéž.

63 NA, f. Jan Jelínek, nezprac., ka 1, Kapesní kalendáŕ z r. 1959.

64 NA, f. Jan Jelínek, nezprac., ka 1, Vzpomínky Jana Jelínka ze dne 10. 3. 1969.

65 NA, f. Jan Jelínek, nezprac., ka 1, Usnesení okresního soudu v Lounech ze dne 24. 9. 1990.

66 NA, f. Jan Jelínek, nezprac, ka1, Rozhodnutí Ministerstva spravedlnosti o odškodnění Jana Jelínka ze dne 31. 7. 1992.
} 
Léta se marně snažil získat státní souhlas, aby mohl opět působit jako duchovní. Nakonec se mu to podařilo a stal se pomocným farářem bez nároku na plat. Po roce $1989^{67}$ Jan Jelínek působil jako kazatel v Oráčově do r. 2005, do svých 93 let. Když mu bylo 90 let, pomohl zajistit rekonstrukci oráčovského kostela, kterou částečně hradil ze svých vlastních úspor a osobně řídil také stavební práce.

V roce 2007 zaslali rodáci obce Kupičov prezidentovi České republiky návrh na udělení státního vyznamenání Janu Jelínkovi, žel, nebyli vyslyšeni. ${ }^{68}$ Této pocty se mu nakonec dostalo. Dne 28. ř́jna 2019 kdy Jana Jelínka vyznamenal prezident republiky Miloš Zeman Řádem Tomáše Garigua Masaryka I. třídy. Další velké pocty se mu dostalo v Polsku. V roce 2017 byl v Zahradě spravedlivých ve varšavské čtvrti Muranow ${ }^{69}$ jako poděkování Janu Jelínkovi za záchranu polských obyvatel vysazen strom a instalován pamětní kámen $\mathrm{s}$ jeho jménem. Jeho statečné činy připomíná rovněž pamětní deska na kostele v Oráčově. K slavnostnímu odhalení pamětní desky došlo 18 . května $2019 .^{70}$ Iniciátorem pamětní desky se stalo občanské sdružení Exulant, ${ }^{71}$ které od roku 1990 sdružuje potomky pobělohorských exulantů.

Kdybychom měli vystihnout životní krédo Jana Jelínka, našli bychom ho v jednom z jeho zápisníků. Je uložený v Národním $\operatorname{archivu}^{72}$ a Jelínek $\mathrm{z}$ textu čerpal při přípravě svých kázání. Obsahuje moudrost, která charakterizuje přesně hodnoty, kterými se Jan Jelínek v celém svém životě ř́dil:

„Ptali se jednoho mudrce, která hodina v lidském životě
je nejdìležitější,
který člověk je nejdůležitější a který skutek je
nejdůležitější.
Odpověděl: ,Nejdůležitějši hodina je vždy ta přitomná,
nejdůležitějši člověk je vždy ten, který právě stojí pred
tebou
a nejdůležitější skutek je vždy prokázat člověku dobro. "“

67 Politickou změnu v roce 1989 uvítal, následovalo však zklamání: „, Duchovně jsme v otroctví dále. Člověk se neobrací k Bohu, ale chce být pánem všeho. “ Český Schindler Jan Jelínek, Magazín Práva, 18. 10. 2008, s. 17. In: NA, f. Jan Jelínek, nezprac., ka 1.

68 Návrh na státní vyznamenání pro Jana Jelínka zpracovala PhDr. Miloslava Žáková, CSc. Její návrh podpořilo 87 bývalých obyvatel obce Kupičov. Kopie návrhu viz NA, f. Jan Jelínek, nezprac., ka 1.

${ }^{69}$ Varšavskou čtvrt' Muranow obývali v meziválečném období výhradně Židé. Za druhé světové války se z ní stalo ghetto, které bylo nacisty po krvavém potlačení povstání srovnáno se zemí. Na ruinách domů a sklepů vyrostla po válce moderní obytná čtvrt'. Nachází se zde Muzeum dějin polských Židů a Zahrada spravedlivých. Zahradu založili jako připomínku těch, kteří měli odvahu postavit se proti nelidským totalitním režimům, zachraňovali lidské životy, pomáhali pronásledovaným a bránili lidskou důstojnost. Každým rokem v Zahradě odhalí tři pamětní kameny a zasadí tři stromy. V roce 2017 odhalili spolu s kamenem pro Jana Jelínka také pamětní kámen připomínající ruskou básnířku a disidentku Natalii Gorbaněvskou (jednu z pěti lidí protestujících v roce 1968 v Moskvě proti zásahu vojskVaršavské smlouvy v Československu) a argentinského diplomata Roberto Kozaka (v sedmdesátých letech zachránil mnoho lidí pronásledovaných chilským režimem Augusta Pinocheta, mezi nimi i současnou chilskou prezidentku Verónicu Michelle Bachelet Jeri).

Viz Jan Bistranin, Jan Jelinek v „Zahradě spravedlivých “ ve Varšavě, Exulant 2017, č. 4, dostupné z: https://protestant.evangnet.cz/jan-jelinek-v-zahrade-spravedlivych-ve-varsave, staženo 28. 1.2020.

70 Josef Rod, Manželé Jelínkovi zachránili desitky životů. Hrdinům odhalí pamětní desku, Rakovnický deník, 16. 5. 2020, dostupné z: https://rakovnicky.denik.cz/zpravy_region/manzele-jelinkovi-zachranili-desitky-zivotu-hrdinum-odhali-pametni-desku-20190515.html, staženo 17.2.2020.

71 Jedním z iniciátorů vzniku tohoto sdružení se stal rovněž Jan Jelínek. Viz Josef ČÁP, Pocta manželi̊m Jelínkovým, Informační věstník zapsaného spolku Exulant, 2020, č. 49, s. 6.

72 NA, f. Jan Jelínek, nezprac., ka 5, Př́iběhy, které se skutečně staly. 1. díl, s. 51. 